\title{
Diagnosis of Imported Monkeypox, Israel, 2018
}

\author{
Noam Erez, ${ }^{1}$ Hagit Achdout, ${ }^{1}$ Elad Milrot, \\ Yuval Schwartz, Yonit Wiener-Well, Nir Paran, \\ Boaz Politi, Hadas Tamir, Tomer Israely, \\ Shay Weiss, Adi Beth-Din, Ohad Shifman, \\ Ofir Israeli, Shmuel Yitzhaki, Shmuel C. Shapira, \\ Sharon Melamed, Eli Schwartz
}

We report a case of monkeypox in a man who returned from Nigeria to Israel in 2018. Virus was detected in pustule swabs by transmission electron microscopy and PCR and confirmed by immunofluorescence assay, tissue culture, and ELISA. The West Africa monkeypox outbreak calls for increased awareness by public health authorities worldwide.

$\mathrm{M}$ onkeypox is a zoonotic disease caused by monkeypox virus, an orthopoxvirus closely related to variola virus, the causative agent of smallpox. Human cases were first described in 1970; in subsequent decades, sporadic outbreaks were reported in Africa. Mortality rates are $1 \%$ $10 \%(1,2)$. The 2 clades, Congo-Basin and West African, each cause disease; the West African clade is considered to be less virulent and is associated with a lower mortality rate (3). Nevertheless, this clade is responsible for the largest documented monkeypox outbreak in West Africa (132 confirmed cases in Nigeria) (4). Human infection with monkeypox occurred in the United States in 2003, when imported animals from Africa infected pet prairie dogs (5). In September 2018 in the United Kingdom, 2 imported cases of monkeypox were detected in persons from Nigeria (6); a healthcare worker (HCW) acquired nosocomial infection from 1 of those patients. We report a case of monkeypox in Israel.

\section{The Study}

On October 4, 2018, a 38-year-old man sought care for generalized rash and fever at the Department of Emergency Medicine at Shaare-Zedek Medical Center, Jerusalem, Israel. This Israel resident had returned from Port Harcourt,

Authorship affiliations: Israel Institute for Biological Research, Ness-Ziona, Israel (N. Erez, H. Achdout, E. Milrot, N. Paran, B. Politi, H. Tamir, T. Israely, S. Weiss, A. Beth-Din, O. Shifman, O. Israeli, S. Yitzhaki, S.C. Shapira, S. Melamed); Shaare-Zedek Medical Center, Jerusalem, Israel (Y. Schwartz, Y. Wiener-Well); Tel Aviv University, Tel Aviv, Israel (E. Schwartz)
Rivers State, Nigeria, where he had worked a desk job for the previous 10 years. On September 17, during his last trip to Nigeria, he had disposed of 2 rodent carcasses at his residence. He returned to Israel on September 23 and on September 29 noticed 2 itchy lesions on his penis shaft. The next day, he had fever $\left(38.8^{\circ} \mathrm{C}\right)$ and chills and started selfmedicating with nonsteroidal antiinflammatories and oral penicillin. On October 1, an erythematous rash appeared first on his face and later on his trunk and extremities.

Examination at Shaare-Zedek Medical Center on October 4 revealed that the patient was febrile and had a nonblanching maculopapular rash on his face (Figure 1, panel A), neck, trunk, and lower and upper extremities; several lesions on his palms and soles; 2 ulcers with an erythematous base on his penis shaft; and bilateral enlarged and tender lymph nodes in his groin. Blood test results indicated moderate thrombocytopenia $(98,000$ platelets $/ \mu \mathrm{L})$ and mild hepatitis. One lesion on the posterior aspect of his left arm (Figure 1, panel B) was suspected to be an eschar, raising the possibility of rickettsialpox. The patient was therefore hospitalized and administered oral doxycycline. His condition improved, and the next day he was discharged with doxycycline and instructions to remain isolated at home.

At a follow-up visit 2 days later (October 7), he was afebrile. The rash was locally synchronous and had progressed from maculopapular to vesicular and pustular; some lesions displayed black umbilication and crusting (Figure 1, panels C, D). Oral examination revealed bilateral tonsillar enlargement and ulcers in the posterior pharynx. Serology results were positive for varicella IgG (past infection) and negative for Coxiella burnetii, Rickettsia conori, Rickettsia typhi, Brucella spp., Treponema pallidum, and antigen/antibody combination for HIV. Pustular samples were negative for herpes simplex virus by PCR. Because of the rash characteristics and the patient's travel history, monkeypox was suspected.

Samples were sent to the Israel Institute for Biological Research, Ness-Ziona, Israel, and processed in Biosafety Level 3 laboratories. The pustule sample was processed for PCR analysis and transmission electron microscopy. Vero cells were infected for immunofluorescence assay and monitored for cytopathic effect. For transmission electron microscopy, particles were enriched by using a Beckman Airfuge (https://www.beckman.com) before negative staining with phosphotungstic acid. 
The sample exhibited numerous brick-shaped particles, characteristic of orthopoxviruses. Particles were observed to be in clusters (up to 10 virions in each cluster) embedded in skin tissue and as single virions (Figure 2, panels A, B). Viral particle dimensions ( \pm SD) were $281 \pm$ $18 \mathrm{~nm} \times 220 \pm 17 \mathrm{~nm}(\mathrm{n}=24)$, in accordance with previously reported dimensions for monkeypox virus (5).

PCR diagnosis was based on specific primers to discriminate between the West African (581 bp) and the Congo-Basin ( $832 \mathrm{bp}$ ) clades by product size (7). The PCR

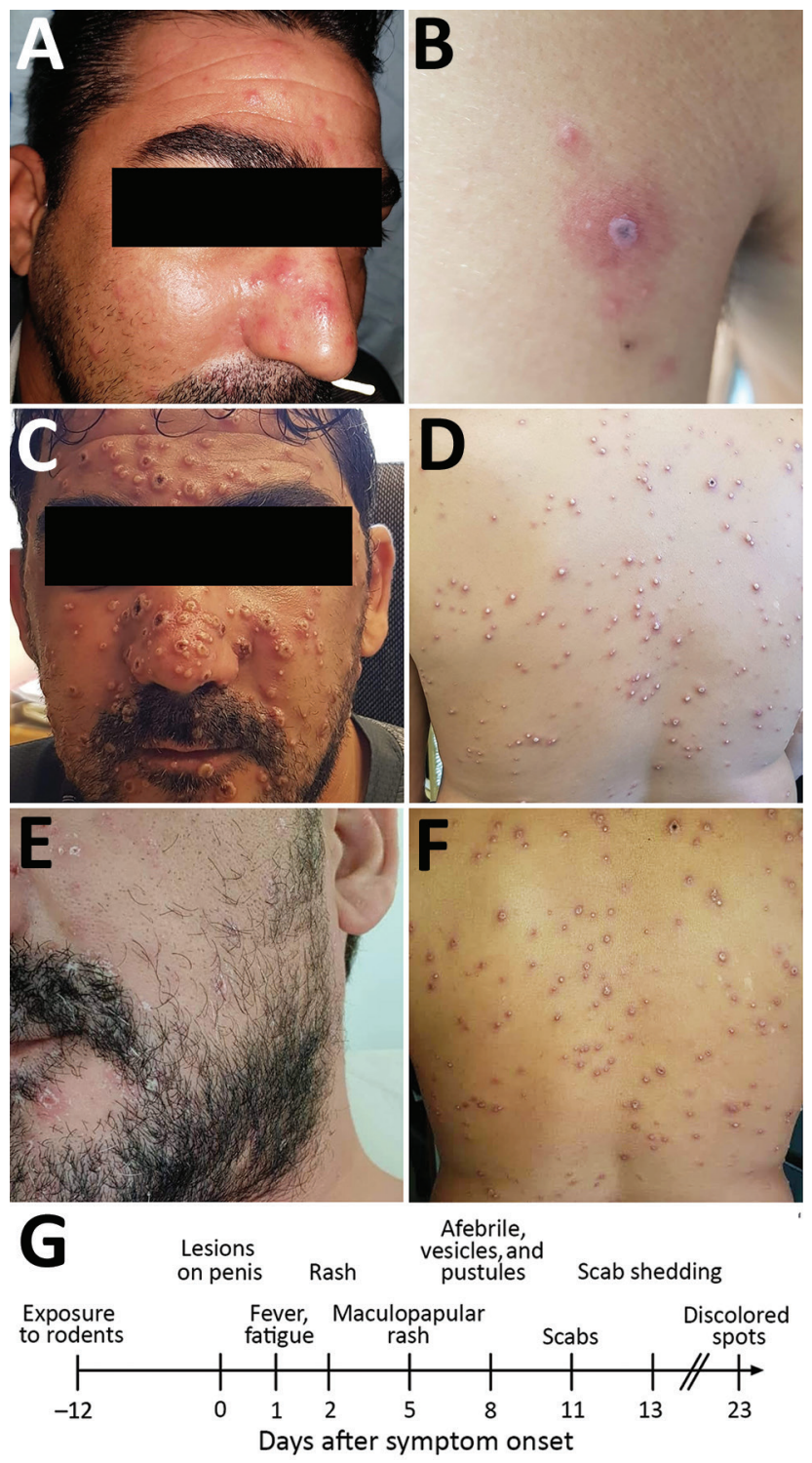

Figure 1. Dermal manifestations of monkeypox on patient in Israel, 2018. Maculopapular rash was apparent on the face (A) and body on the day of hospital admission. A lesion on the left proximal extremity (B) was suspected to be a rickettsial eschar. After 3 days, the rash changed into vesicles and pustules on the face (C) and body (D). Skin resolution was apparent 13 days after admission; pustules and vesicles crusted and were shed (E, F). G) Timeline of disease progression. product size corresponded to that of the West African clade currently circulating in Nigeria (8). This finding was confirmed by high-throughput sequencing.

Within 24 hours of infection, cytopathic effect was observed in Vero cells, exhibiting typical monolayer separation and cell rounding (Figure 2, panel C). The result of immunofluorescence assay with a specific antibody against orthopoxviruses was positive; some cells exhibited viral factories, typical for orthopoxvirus infection (Figure 2, panel D) (9).

The patient was instructed to remain isolated in his residence until he had fully recovered. Days after he returned home, the pustules turned to scabs $(0.3-0.8 \mathrm{~mm}$ in diameter) and were shed (Figure 1, panels E, F). Concomitant with recovery, antibodies against orthopoxvirus and a neutralizing antibody titer $(50 \%$ plaque reduction neutralization test titer $=134$ ) developed, comparable to those of smallpox-vaccinated humans (10). Of note, scabs collected from the patient during recovery, then homogenized and tested for monkeypox virus, contained viable viral loads of $10^{5}-10^{7} \mathrm{PFU} / \mathrm{scab}$.

All of the patient's contacts in Israel (5 household members and $11 \mathrm{HCWs)}$ were offered smallpox vaccination, but only $1 \mathrm{HCW}$ agreed. All contacts were followed up for 21 days; no virus transmission was detected.

\section{Conclusions}

Since the first documented case of human monkeypox in 1970, sporadic outbreaks have been reported, especially in the Congo Basin and West Africa. Contributing to the increased frequency of such occurrences were discontinued vaccination against smallpox, increased interaction with wildlife because of deforestation and population movement, consumption of bushmeat, and increased population density $(11,12)$. Although most infections are acquired from wildlife, human-to-human transmission has been reported, as in the 1996-1997 outbreak in the Democratic Republic of the Congo (13) and the current outbreak in West Africa (8). The availability and speed of international transportation combined with the natural progression of the disease (long incubation and prodromal periods, up to 21 days combined) increase the risk for monkeypox spread from rural regions into urban areas and to countries outside Africa. Indeed, during September and October 2018, monkeypox was diagnosed in the United Kingdom and Israel $(6,14)$.

Thus far, all imported cases of monkeypox in humans (United States in 2003, United Kingdom and Israel in 2018) have involved the West African clade of the virus $(3,6)$. After a similar incubation period (12 days), all patients had fever and chills, lymphadenopathy, and skin lesions $(5,6)$. Although the patient in Israel had numerous vesiculopustules on his face and body, the patients involved in the US outbreak had substantially fewer (1-50) and reported a 

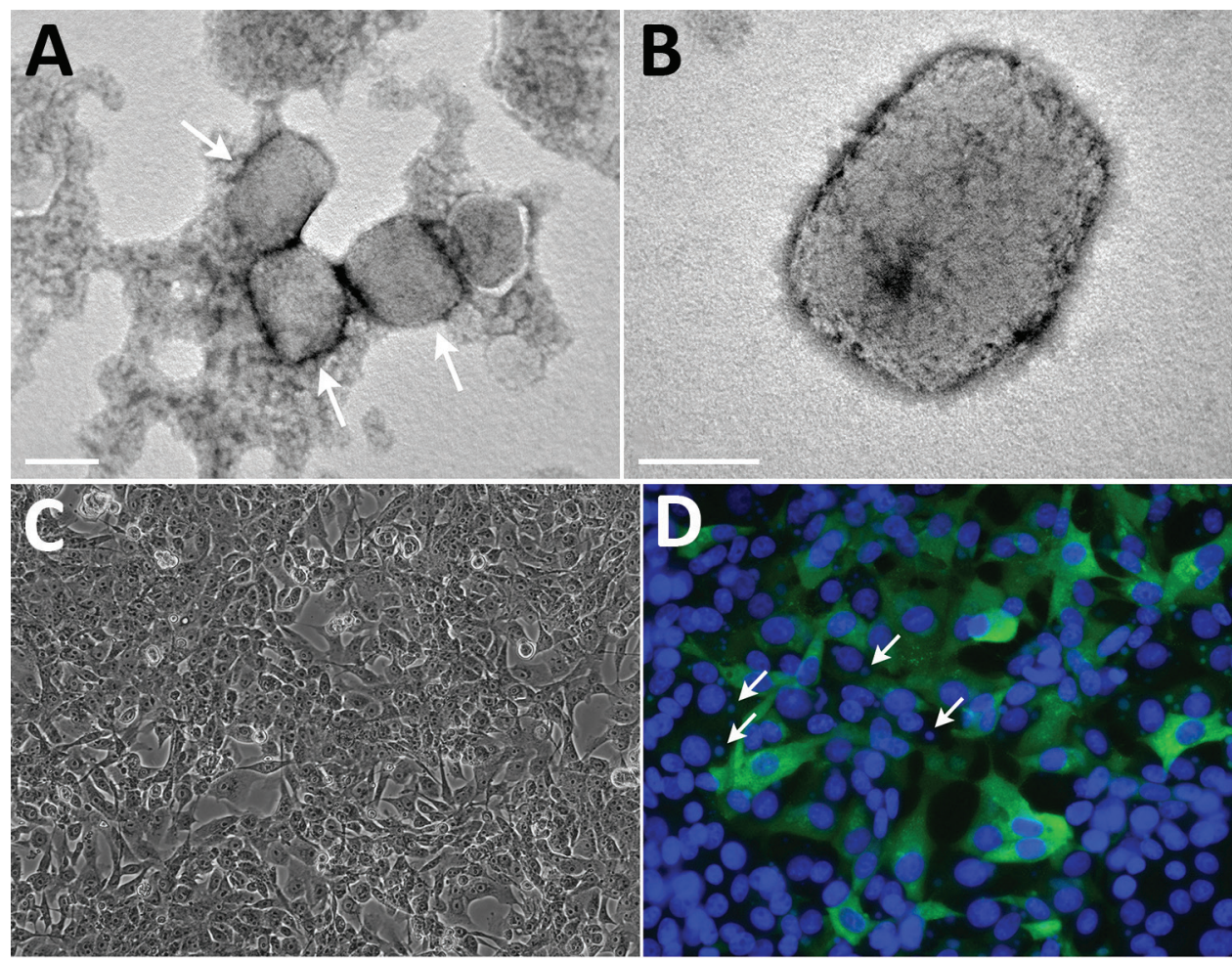

Figure 2. Transmission electron microscopy and cell culturebased diagnosis of monkeypox in patient in Israel, 2018. Virus particles were detected in lesion samples as either virion aggregates (arrows) (A) or individual virions $(B)$ with a typical brick shape. Infected Vero cells depicted typical cytopathic effect, exhibiting cell detachment and rounding. Scale bar in $A$ indicates $0.2 \mu \mathrm{m}$; scale bar in $B$ indicates $100 \mathrm{~nm}$.

C) Infected Vero cells depicting typical cytopathic effect: cell detachment and rounding. Original magnification $\times 10$. D) Immunofluorescent staining of infected Vero cells: DNA (DAPI [4',6-diamidino-2-phenylindole] stain, blue) and monkeypox virus (green); viral factories are evident (arrows). Original magnification $\times 25$. persistent cough, which the patient from Israel did not report. Of note, the first sign noted by the Israel and UK patients was groin lesions (6). Although past reports considered the Congo-Basin clade to be more virulent $(2,3,12)$, recent reports show that the West African clade can also cause disseminated disease and can be transmitted from human to human $(4,8)$.

For this study, we used multiple diagnostic approaches. The virus was detected in pustule swab specimens by transmission electron microscopy and PCR within 3 hours of sample arrival and confirmed by immunofluorescence assay, tissue culture, and ELISA for orthopoxvirus antigens.

The very high virus titers contained by pustules and scabs, as demonstrated in this case, increase the risk for human-to-human transmission and environmental spread. To prevent further transmission, HCWs should implement safety practices and local authorities should map contacts and consider use of smallpox vaccines or antiviral drugs $(14,15)$, according to risk assessment.

\section{Acknowledgment}

We thank Itai Glinert for help with the manuscript.

\section{About the Author}

Drs. Erez and Achdout are researchers at the Department of Infectious Diseases, Israel Institute for Biological Research, Ness-Ziona, Israel. Their research interests include immune response to vaccines and viral infections.

\section{References}

1. Di Giulio DB, Eckburg PB. Human monkeypox: an emerging zoonosis. Lancet Infect Dis. 2004;4:15-25. http://dx.doi.org/ 10.1016/S1473-3099(03)00856-9

2. Breman JG, Kalisa-Ruti, Steniowski MV, Zanotto E, Gromyko AI, Arita I. Human monkeypox, 1970-79. Bull World Health Organ. 1980;58:165-82.

3. Likos AM, Sammons SA, Olson VA, Frace AM, Li Y, Olsen-Rasmussen M, et al. A tale of two clades: monkeypox viruses. J Gen Virol. 2005;86:2661-72. http://dx.doi.org/10.1099/ vir.0.81215-0

4. Petersen E, Abubakar I, Ihekweazu C, Heymann D, Ntoumi F, Blumberg L, et al. Monkeypox - enhancing public health preparedness for an emerging lethal human zoonotic epidemic threat in the wake of the smallpox post-eradication era. Int J Infect Dis. 2019;78:78-84. http://dx.doi.org/10.1016/j.ijid.2018.11.008

5. Reed KD, Melski JW, Graham MB, Regnery RL, Sotir MJ, Wegner MV, et al. The detection of monkeypox in humans in the Western Hemisphere. N Engl J Med. 2004;350:342-50. http://dx.doi.org/10.1056/NEJMoa032299

6. Vaughan A, Aarons E, Astbury J, Balasegaram S, Beadsworth M, Beck CR, et al. Two cases of monkeypox imported to the United Kingdom, September 2018. Euro Surveill. 2018;23. http://dx.doi.org/10.2807/1560-7917.ES.2018.23.38.1800509

7. Shchelkunov SN, Gavrilova EV, Babkin IV. Multiplex PCR detection and species differentiation of orthopoxviruses pathogenic to humans. Mol Cell Probes. 2005;19:1-8. http://dx.doi.org/ 10.1016/j.mcp.2004.07.004

8. Yinka-Ogunleye A, Aruna O, Ogoina D, Aworabhi N, Eteng W, Badaru S, et al. Reemergence of human monkeypox in Nigeria, 2017. Emerg Infect Dis. 2018;24:1149-51. http://dx.doi.org/ w10.3201/eid2406.180017

9. Smith GL, Vanderplasschen A, Law M. The formation and function of extracellular enveloped vaccinia virus. J Gen Virol. 2002;83:2915-31. http://dx.doi.org/10.1099/0022-1317$83-12-2915$ 
10. Orr N, Forman M, Marcus H, Lustig S, Paran N, Grotto I, et al.; Vaccinia Study Group, Medical Corps, Israel Defense Force; Vaccinia Study Group, Israel Institute for Biological Research. Clinical and immune responses after revaccination of Israeli adults with the Lister strain of vaccinia virus. J Infect Dis. 2004;190:1295-302. http://dx.doi.org/10.1086/423851

11. Nolen LD, Osadebe L, Katomba J, Likofata J, Mukadi D, Monroe B, et al. Introduction of monkeypox into a community and household: risk factors and zoonotic reservoirs in the Democratic Republic of the Congo. Am J Trop Med Hyg. 2015;93:410-5. http://dx.doi.org/10.4269/ajtmh.15-0168

12. McCollum AM, Damon IK. Human monkeypox. Clin Infect Dis. 2014;58:260-7. http://dx.doi.org/10.1093/cid/cit703

13. Centers for Disease Control and Prevention. Human monkeypox-Kasai Oriental, Democratic Republic of Congo,
February 1996-October 1997. MMWR Morb Mortal Wkly Rep. 1997;46:1168-71.

14. Angelo KM, Petersen BW, Hamer DH, Schwartz E, Brunette G. Monkeypox transmission among international travelers serious monkey business? J Travel Med. 2019. http://dx.doi.org/ $10.1093 / \mathrm{jtm} / \mathrm{taz} 002$

15. Melamed S, Israely T, Paran N. Challenges and achievements in prevention and treatment of smallpox. Vaccines (Basel). 2018;6:E8. http://dx.doi.org/10.3390/vaccines 6010008

\footnotetext{
Address for correspondence: Sharon Melamed, Israel Institute for Biological Research, Department of Infectious Diseases, Ness-Ziona 74100, POB 019, Israel; email: sharonm@iibr.gov.il
}

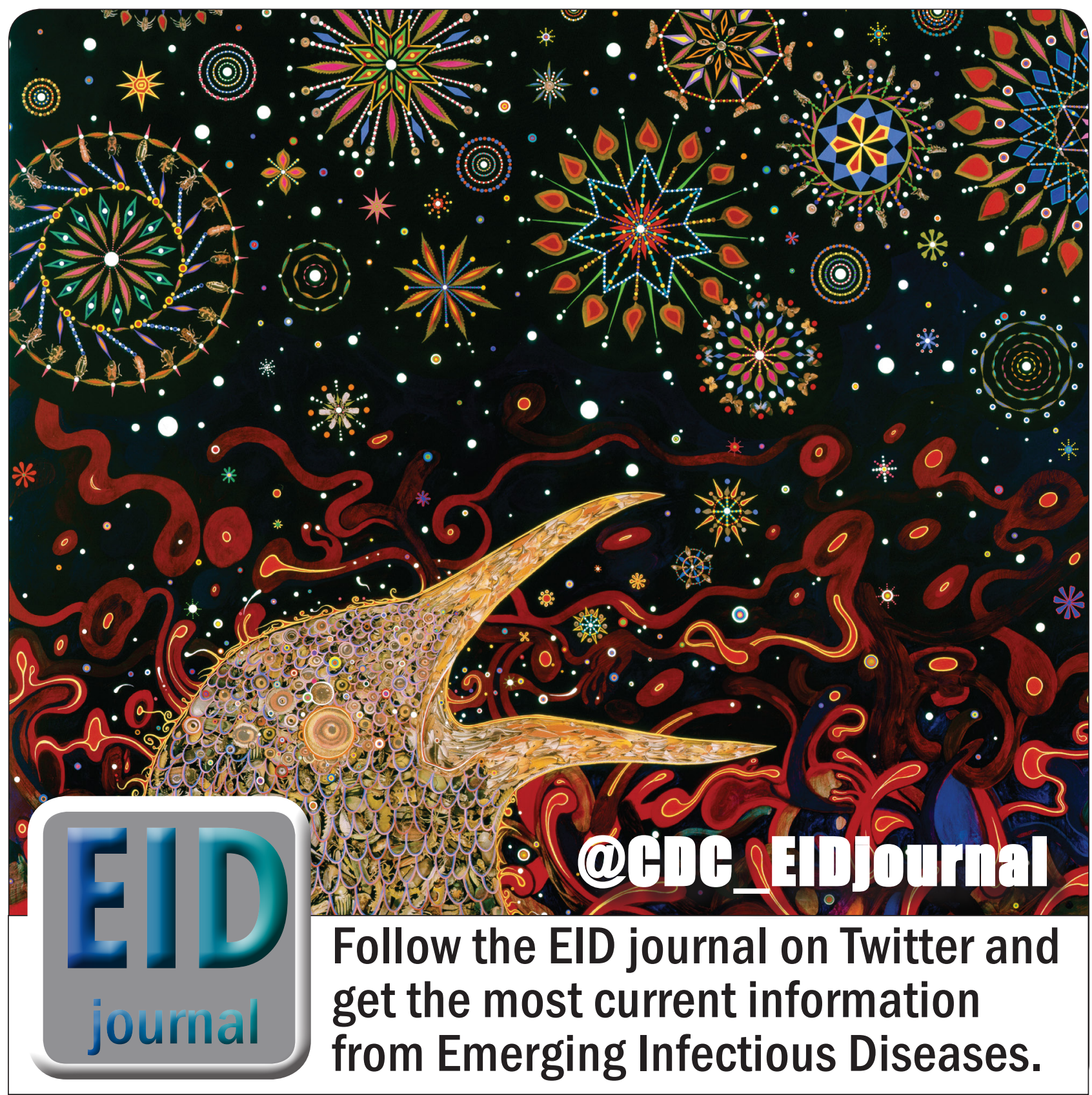

